SCIENCE AND SOCIETY

\title{
Wildlife cancer: a conservation perspective
}

\section{Denise McAloose and Alisa L. Newton}

Abstract | Until recently, cancer in wildlife was not considered to be a conservation concern. However, with the identification of Tasmanian devil facial tumour disease, sea turtle fibropapillomatosis and sea lion genital carcinoma, it has become apparent that neoplasia can be highly prevalent and have considerable effects on some species. It is also clear that anthropogenic activities contribute to the development of neoplasia in wildlife species, such as beluga whales and bottom-dwelling fish, making them sensitive sentinels of disturbed environments.

Cancer is an important cause of morbidity and mortality in several wildlife species. Virus-associated, carcinogen-related and novel transmissible tumours currently impact threatened and protected species. Cancer can affect conservation outcomes by reducing reproductive success, altering population dynamics (see Glossary) or directly or indirectly leading to population declines. In one species, the Tasmanian devil (Sarcophilus harisii), high cancer incidence threatens the species with extinction.

The links between animal and human health and scientific discovery are long standing. Viral oncogenesis is a familiar concept in both animal and human fields of medicine, and the study of animal viruses has led to important insights into the molecular basis of cancer. Discovering the transmissible effects of the Rous chicken sarcoma virus in 1911 (REF. 1) led to the eventual identification of the $\underline{S R C}$ oncogene and its role in human cancer. Identification of the Ras oncogene originated from studies of murine leukaemia virus $^{2}$ and our understanding of the crucial role Wnt signalling pathways have in carcinogenesis resulted from studies of mouse mammary tumour virus ${ }^{3}$. It is likely that animals, including wildlife, will continue to contribute to our understanding of cancer biology in the future. Novel allograft tumours in Tasmanian devils and dogs may influence the development of beneficial animal and human cancer immunotherapies, and wildlife that develop cancer from anthropogenic factors will continue to act as sentinels for animal and human health risks. What is learned about cancer through wildlife health monitoring will affect conservation of animals and wild places and affect human health, consistent with the One World, One Health concept (One World, One Health is a registered trademark of the Wildlife Conservation Society) ${ }^{4}$.

\section{Cancer detection and prevalence}

Cancer is a major cause of death in humans. The World Health Organization estimated that in 2007, 7.9 million human deaths globally (approximately $13 \%$ of the total number of deaths) were due to cancer ${ }^{5}$. However, despite its high incidence, cancer as a cause for human extinction is unlikely to warrant much consideration. Until recently, the same could have been said for most wildlife species. In the few surveys that summarized wildlife mortality data, trauma and starvation were most frequently reported as causes of death ${ }^{6,7}$. However, over the past few decades wildlife health monitoring has increased and we are now gaining an improved - and occasionally alarming - perspective about the presence and impact of cancer in endangered species, such as the Tasmanian devil, western barred bandicoot (Perameles bougainville) and Attwater's prairie chicken (Tympanuchus cupido Attwateri), and non-endangered species, such as the beluga whale

\section{(Delphinapterus leucas).}

Evaluating health and diagnosing disease in wild animal populations poses several challenges. As in human medicine, data and sample collection in wildlife is performed by networks of professionals and non-professionals across many disciplines, including veterinarians, veterinary pathologists, biologists, epidemiologists and citizens in field stations, universities, zoos and communities. Access to live or deceased animals and sample collection can be complicated by environmental obstacles, such as thick jungle or wide dispersal of animals across oceans and vast savannahs, species-specific adaptations, such as flight, or tissue loss through environmental decomposition, predation or post-mortem scavenging. Cancer in wildlife is most commonly detected during post-mortem examination with confirmation through histopathology. Advanced cancer diagnostics, such as computed tomography and magnetic resonance imaging that are available for cancer detection and identification in humans are generally not accessible or are unavailable for wildlife. Techniques such as immunohistochemical staining are of value but have limited applicability in wildlife owing to the species-specific nature of protein targets and consequently the antibodies required for detection. Most animal cancer detection resources and the best developed networks exist in the companion animal and agriculture sectors. Relatively limited resources, human or financial, are dedicated to consistent or widespread wildlife health monitoring and disease diagnostics. For these reasons and those listed above, cancer in wildlife goes largely undetected.

Establishing cancer prevalence is important if we are to understand the effect of cancer in wildlife species and its importance to conservation. However, determining valid cancer prevalence (or prevalence of any disease in wildlife) is not often achieved. Most wild animals live and die in anonymity without being documented in census data, without baseline health information or without the causes of morbidity and mortality ever being determined or recorded. An exception to this general rule are small, geographically isolated populations, such as the critically endangered island fox (Urocyon littoralis), for which population size and animal health can be feasibly monitored and valid disease prevalence can be established ${ }^{8}$. It is more common to determine disease prevalence relative to a sampled group. For example, beluga whales inhabit arctic and subarctic waters along the coasts of Alaska, Canada, Greenland and Russia. The southernmost extent of the range includes an isolated population in the St Lawrence river estuary (SLE) where population and health monitoring have been ongoing for 17 years $^{9}$. In this population, cancer was the second leading cause of death overall (accounting for 18\% of mortalities) with tumours identified in $27 \%$ of adult animals found $\mathrm{dead}^{9}$, a rate that is strikingly similar to that found in humans, in whom cancer is the second leading cause of mortality in the United States and accounts for $22.9 \%$ of all deaths ${ }^{5}$. In this case, cancer prevalence was determined for the local population rather than the species. As the SLE beluga whales are a well-characterized group, accurate data for epidemiological modelling can be applied to the local population; similar disease prevalence and epidemiological investigations can be performed in captive collections of 
animals (BOX 1). In less well monitored or more dispersed populations, disease prevalence is often estimated from retrospective information in the absence of accurate population data, and in many cases small numbers of animals are assumed to be representative of the species as a whole, a situation that may or may not be accurate.

In wildlife with cancer, the focus is generally not on treatment but rather is directed at understanding tumour biology, prevention and intervention strategies in spontaneous tumours, as well as efforts to affect conservation policy or introduce mandatory environmental abatement in anthropogenically induced tumours. Research and resources for investigating wildlife cancer are extremely limited and successful outcomes for wildlife are more likely for tumours arising in association with anthropogenic activities and interventions that also affect humans. In one notable exception, intense activity is currently focused on Tasmanian devils, in which a spontaneous transmissible tumour is spreading to epidemic proportions resulting in devastating effects on the population. In this case, efforts are underway to manage the remaining animals and develop conservation strategies without which species extinction is predicted.

\section{Transmissible allograft cancers}

The Tasmanian devil survives only on the island state of Tasmania, Australia, and is threatened by extinction owing to a contagious cancer, devil facial tumour disease (DFTD) ${ }^{10-13}$. It presents as a focal or multicentric neuroendocrine tumour ${ }^{14,15}$ that generally affects the face and neck and progresses to cause considerable soft tissue disfigurement; metastasis, most commonly to regional lymph nodes or the lungs, occurs in up to $65 \%$ of the animals ${ }^{14}$. Complications associated with tumour growth or metastasis result in a mortality rate of $100 \%$ in affected animals. In the early 1990s, Tasmanian devils were considered to be common and the Tasmanian devil population was estimated at 150,000 individuals $^{12}$; however, since its first observation in 1996 (REFS 13,16), DFTD has decimated the Tasmanian devil population ${ }^{12}$ resulting in a population decline of $53 \%^{11}$ and the listing of the Tasmanian devil as an endangered species by the International Union for the Conservation of Nature and Natural Resources (IUCN) in 2008. Current disease modelling predicts declines of $90 \%$ across $60 \%$ of territories with diseased Tasmanian devils and a $70 \%$ reduction of the entire population over the next 10 years ${ }^{12,17,18}$. At these rates, extinction is a real possibility.

\section{Box 1 | Cancer in captive animals}

Disease monitoring of captive animals, primarily those in zoos and aquariums, reveals a wide range of spontaneous neoplasia across the vertebrate taxa. Retrospective mortality studies in two zoos have shown similar rates of neoplasia in captive wildlife to those in domestic animals ${ }^{128,129}$. Tumours, such as chromatophoromas in snakes ${ }^{130,131}$, hepatocellular or biliary carcinomas in bears ${ }^{132,133}$, and renal, biliary and apocrine tumours in black-footed ferrets ${ }^{134}$, are known to wildlife pathologists through various descriptions in the literature. Unusual tumours, such as Kaposiform hemangioendothelioma in a tamarin (Sanguinus oedipus) or multilobular osteoma and chondroma in an African wild dog (Lycaon pictus) have also been observed (D.M., unpublished observations). In a few situations, management practices for captive animals have been associated with cancer development. For example, subcutaneously implanted microchips used for the permanent identification of individual animals have been associated with soft tissue sarcomas in laboratory mice ${ }^{135,136}$ and rats $^{137}$, as well as in a few zoo animals - degus (Octogon degus), feathertail glider (Acrobates pygrnaeus) ${ }^{138}$ and Egyptian fruit bat (Rousettus aegyptiacus) ${ }^{139}$. Additionally, melengestrol acetate contraception in exotic zoo felids, such as tigers, lions and jaguars, is associated with a high incidence of mammary gland carcinomas ${ }^{140}$ $\left(94 \%\right.$ in one report $\left.{ }^{141}\right)$ and is therefore no longer a recommended method of contraception in these animals.

Evidence supports a novel mechanism of DFTD persistence and spread within the population: allograft transmission. Although initial transmission trials are not yet published, transplantation of cultured DFTD cells and surgically implanted tumour tissue has produced tumours in unaffected Tasmanian devils ${ }^{18}$. Further evidence supporting the allograft theory includes failure to identify pathogens (such as a virus) using routine light and electron microscopy ${ }^{14}$. Additionally, in all animals studied, karyotype analysis shows 13 rather than 14 chromosomes and consistent genetic aberrations, including loss of both sex chromosomes, no copies of chromosome 2, loss of 1 copy of chromosome 6 and the addition of 4 unidentified marker chromosomes (M1-M4) in tumour cells compared with host cells ${ }^{19}$. Furthermore, evaluation of multiple microsatellite and major histocompatibility complex (MHC) loci has confirmed genotypes that are identical in Tasmanian devil tumours but differ from their hosts, consistent with an exogenous tumour source ${ }^{20}$. Despite having a competent immune system ${ }^{21-23}$, ease of tumour spread is thought to be related to low MHC class I diversity and limited cell-mediated immunological reaction and activation (rather than the failure of immune cells to proliferate) to tumour cells in Tasmanian devils ${ }^{12,14,20}$.

Canine transmissible venereal sarcoma (CTVS) is the only other cancer in wildlife known to be naturally transmitted through an allograft ${ }^{24}$; the unintentional transfer of undiagnosed neoplastic cells through organ transplantation is the only comparison in humans ${ }^{25-27}$. CTVS was first described and transmitted between dogs in 1876 by Novinski (reviewed in REF. 24). It is a histiocytic tumour ${ }^{28}$ that generally affects the external genital mucosa of sexually active dogs and is transmitted during breeding and the licking or sniffing of affected tissue $e^{24,29,30}$. The tumour is locally extensive more often than metastatic and in many animals it regresses within several months; morbidity rather than mortality is therefore more common in CTVS. The tumour is present in free-ranging dogs worldwide and is most prevalent in tropical and subtropical countries $^{29}$. CTVS is thought to have developed in a wolf (Canis lupus) or East Asian breed of $\operatorname{dog} 200$ to 2,500 years ago ${ }^{24,29-31}$, and on the basis of genetic markers, Murgia et al. suggest that CTVS arose from a single common ancestral neoplastic clone that subsequently diverged into the two current genetically distinct tumour subtypes that exist in dogs today ${ }^{24}$.

Similarly to DFTD, experimental studies have confirmed that CTVS is a clonal cell allograft. Supporting evidence includes transmission trials ${ }^{32}$, common specific chromosomal anomalies, such as tumour markers (in particular the long interspersed nuclear element insertion near $M Y C^{24,31}$ ), and genetic comparisons of the $\mathrm{MHC}$, microsatellites and mitochondrial DNA between tumour and host cells ${ }^{24}$. Impaired differentiation of dendritic cells, downregulation of classical MHC class I and absence of MHC class $\mathrm{II}^{24,33,34}$ (rather than low MHC diversity as in DFTD) are recognized as factors in host immune system evasion and successful transmission and progression in $\mathrm{CTVS}^{24,27,34}$. Circulating anti-tumour antibodies in affected dogs are implicated in natural tumour regression ${ }^{16,32}$, which if complete is associated with subsequent resistance ${ }^{29,32}$. Recent scientific interest in characterizing immunological reactions between the tumour and host, including the 
role of tumour and host cytokine expression, such as transforming growth factor- $\beta 1$ (TGF- $\beta 1$ ), interleukin- 6 and interferon- $\gamma$, in this unique canine tumour includes consideration of the potential applicability of CTVS as an in vivo model for developing cancer immunotherapies in humans ${ }^{34,35}$.

Genetic diversity is a common topic of discussion and scientific debate in the conservation community. Low MHC diversity is implicated as a factor in disease susceptibility owing to its crucial role in immune system surveillance and resistance to infectious disease; it is of special concern in endangered species, such as the cheetah (Acinonyx jubatus). Low MHC diversity is thought to be important to the high susceptibility of cheetahs to infectious diseases, such as feline coronavirus ${ }^{36}$ and the unusually high acceptance of tissue allografts between cheetahs ${ }^{37}$. Low MHC diversity has been implicated in DFTD transmission and may have been important in the early development of CTVS ${ }^{24}$.

Current evidence and disease modelling suggest that transmission of DFTD and CTVS occurs in a frequency-dependent ${ }^{10,11,38,39}$ rather than a density-dependent manner. In frequency-dependent disease transmission models, transmission rate depends on the frequency of contact with an infected host and is independent of population size (for example, human sexually transmitted diseases are often modelled in this manner). If the modelling is correct, DFTD could therefore lead to the extinction of the Tasmanian devil despite its decreasing population density. In classical density-dependent disease transmission models (commonly applied to infectious diseases, such as measles or influenza) there is a population threshold below which disease is not maintained in the host $^{40,41}$ and in which disease disappears in the absence of alternative disease reservoirs. Recent modelling by Hilker et al. ${ }^{42}$ suggests that there are certain conditions under which density-dependent disease transmission could lead to extinction in the absence of reservoirs, such as when there is a strong Allee effect ${ }^{42}$ as is proposed in the predatorprey relationship between golden eagles and the critically endangered island fox ${ }^{43}$. If DFTD transmission were density rather than frequency dependent, extinction could also potentially occur under certain densitydependent conditions.

DFTD is incurable and unpreventable. In an effort to avoid species extinction, scientists and conservationists are considering establishing isolated assurance colonies of tumour-free animals in geographically restricted areas in Tasmania or zoos to guard against ongoing population declines ${ }^{44}$ while preventive therapies are developed and tested. It is a race against time to ensure the survival of the Tasmanian devil. As the population loses ground to the disease, the Tasmanian devil's crucial role as the top carnivorous marsupial in the Tasmanian ecosystem and its survival will be challenged by native predators, such as the spottedtail quoll (Dasyurus maculates) and Eastern quoll (Dasyurus viverrinus), as well as introduced species, such as the fox and domestic cat (Felis catus) $)^{44}$. If efforts fail and the Tasmanian devil disappears, the Tasmanian devil's role in the Tasmanian ecosystem and its contribution to biodiversity will be lost forever and DFTD will represent the first known instance of a contagious cancer causing the extinction of a species.

\section{Virus-associated tumorigenesis}

The biology of DFTD and its devastating and rapid effects on the Tasmanian devil population are unique regardless of species. More commonly recognized mechanisms of tumorigenesis in both animals and humans include mutations of proto-oncogenes involved in cell cycle regulation, signal transduction and tumour suppression (such as Ras, Wnt or p53) or the effects of viral oncogenes, such as SRC. The effects and implications of oncogenic viruses and mechanisms

\section{Glossary}

Allee effect

A decrease in population fitness, such as population

decline, at low population density.

Benthic

In the lowest ecological regions (such as the sediment surface) of a body of water.

Cetacean

An animal in the order Cetacea; includes, whales, dolphins and porpoises.

\section{Cholangioma}

A benign tumour of the intrahepatic bile ducts.

\section{Chromatophoroma}

Tumour of the pigment-producing, light-reflecting cells, xanthophores, erythrophores and iridiphores, in vertebrate and invertebrate species, such as amphibians, fish, reptiles, crustaceans and cepahalopods.

\section{Fibropapillomatosis}

A condition characterized by the presence of proliferative neoplasms containing superficial epidermal and subjacent dermal tissue.

\section{IUCN}

The International Union for Conservation of Nature and

Natural Resources is a global environmental network created in 1948 consisting of government,

non-governmental organizations and scientific members of tumorigenesis in most wildlife species are poorly understood; however, in some species these issues and the consequences for conservation are in the process of being elucidated.

Attwater's prairie chickens and western barred bandicoots are endangered largely because of habitat destruction ${ }^{45,46}$ and, in the case of the bandicoot, introduced predators such as foxes (Vulpes vulpes) and domestic cats ${ }^{46}$. Wild Attwater's prairie chicken populations totalled less than 100 by the mid $1990 \mathrm{~s}^{47}$ and fewer than several thousand western barred bandicoots are thought to survive today ${ }^{48}$. Captive breeding programmes in both species were established in the 1990s but have been hampered by cancer-causing oncogenic viruses.

Reticuloendotheliosis viruses (REVs), a group of avian gammaretroviruses that are similar to mammalian type $\mathrm{C}$ retroviruses $^{47,49}$, are associated with lymphomas in Attwater's prairie chickens. REV s have been isolated from Attwater's prairie chickens at every captive breeding facility ${ }^{50}$. Natural infection most often causes runting, immunosuppression or a non-neoplastic syndrome associated with high mortality in young birds and B or T cell lymphomas in adults. Experimental infection with REV APC-566 is oncogenic in Japanese quail that works with United Nations agencies, companies and communities towards the development of best practices, policy and environmental laws.

\section{Koch's postulates}

Criteria established by Robert Koch and Friedrich Loeffler in 1884 that established a relationship between a pathogen and disease, including: detection of an organism in hosts suffering from the disease; isolation of the novel organism in pure culture from the original host; transmission of cultured organism causes disease development in the healthy naive experimental host and the isolation of the organism (confirmed identical to the original causative organism) from a lesion in an inoculated host.

Mirex

An organochlorine insecticide that bioaccumulates in the environment and is carcinogenic.

Pinniped

An animal in the orders Carnivora or Odobenidae (walrus), Otariidae (fur seal and sea lion) or Phocidae (true seals).

Population dynamics

Marginal and long-term changes in birth, death immigration, emigration and composition (such as, sex, age and class) of a population.

Sirenian

An animal in the families Trichechidae (manatees) or

Dugongidae (dugongs and sea cows). 
(Coturnix coturnix japonica) and specific pathogen-free chickens and turkeys, causing cancer (primarily lymphoma) as early as 6 weeks after hatching in inoculated quail embryos and 58 days and 13 weeks postinoculation in domestic chickens and turkeys, respectively ${ }^{49}$. Infected Attwater's prairie chickens can be chronically and significantly infected and appear to be clinically healthy for months before disease expression, acting as reservoirs for virus replication and transmission to susceptible birds ${ }^{50}$.

Western barred bandicoots infected with bandicoot papillomatosis carcinomatosis virus type 1 (BPCV1), a novel oncogenic virus that contains genetic material from both papilloma and polyoma viruses, develop cutaneous and mucocutaneous hyperplasias, as well as papillomas, some of which undergo malignant transformation to squamous cell carcinoma $^{51,52}$. In a review of 42 western barred bandicoots with lesions, hyperplasias (71\%), carcinomas in situ (41\%) and squamous cell carcinoma (48\%) were all common, as was the presence of concurrent benign and malignant lesions in individuals $(36 \%)^{52}$. Histologically, positive indirect immunohistochemistry for conserved papillomavirus capsid antigens and identification of viral crystalline arrays in affected keratinocyte nuclei with transmission electron microscopy support a causal relationship between the virus and tumour development ${ }^{52}$.

Virus-associated debilitation and tumour-associated death in REV-and BPCV1-infected Attwater's prairie chickens and western barred bandicoots, respectively, have led to limited population growth and are a risk to the survival of each species. The potential for disease transmission from captive to free-ranging remnant populations has implications for release and reintroduction efforts. Unlike the situation for Attwater's prairie chickens and western barred bandicoots, confirming the effect of virus-associated neoplasia in most wildlife species is often much more challenging. For example, in the marine environment, increases in spontaneous benign and malignant tumours have been identified over the past two decades ${ }^{41,53-56}$. Several viruses seem to have a role in the formation of these tumours but causal relationships remain to be confirmed, and understanding short- and long-term population effects will require ongoing and expanded monitoring.

Green turtles (Chelonia mydas) around the globe are dying from herpes-associated fibropapillomatosis ${ }^{6,54-57}$. These turtles are listed by the IUCN as endangered owing to several factors, including habitat disturbance or destruction, over-harvesting of animals and eggs, boat strike and entanglement in fishing nets that lack turtle excluder devices. In some parts of their range fibropapillomatosis-associated death is now also considered to be a contributing factor to overall population decline. In well-monitored populations, such as those along the coasts of Florida and the Caribbean and Hawaiian Islands, fibropapillomatosis is thought to be an epidemic ${ }^{55,58}$ and dramatic increases in prevalence of as much as $92 \%$ since the early 1980s have been observed ${ }^{56,59}$. Given its global distribution, some have suggested that the disease probably reflects a worldwide panzootic ${ }^{54,55,58}$. Fibropapillomatosis is most commonly observed in green turtles but has been described for all sea turtle species, including the critically endangered leatherback (Dermochelys coriacea $)^{60}$, Kemp's ridley (Lepidochelys kempii) ${ }^{61}$, and hawksbill (Eretmochelys imbricata) ${ }^{62}$ turtles.

Fibropapillomatosis in sea turtles is characterized by benign nodular to papilliferous, fibropapillomas and fibromas rather than fibrosarcomas (which are observed but with less frequency) ${ }^{63}$. Tumours generally arise in the dermis but can be found in internal organs, such as the lung, liver, kidney and heart. Tumours in non-cutaneous sites may reflect metastasis from primary cutaneous tumours or multicentric development that is secondary to systemic virus dissemination, as the virus has been detected with real-time PCR in tumours in cutaneous and non-cutaneous sites ${ }^{63,64}$. Herpes viral inclusions are seen with variable frequency in tumour epithelium ${ }^{55,63,65}$. Debilitation and death from fibropapillomatosis occurs when tumour growth interferes with crucial functions such as feeding, sight and mobility.

The cause, environmental persistence and mode of natural transmission, as well as the cofactors and mechanisms of tumorigenicity of marine turtle fibropapillomatosis, are under investigation. Transmission studies and consensus in the scientific community favours a new chelonian alpha herpesvirus as its cause ${ }^{66,67}$. Viral DNA is consistently found in tumours and tissues of tumour-bearing animals ${ }^{64}$ and inoculation of fibroblasts from turtle fibropapillomas has produced fibromas in immunodeficient mice $^{68}$. However, to date this new turtle virus has not been cultured and Koch's postulates have not yet been demonstrated. Limited experiments on two cultured sea turtle herpesviruses, lung-eye-trachea disease virus and HV2245, have established that both can persist and retain their infectivity outside the host in the marine environment for up to 120 hours $^{69}$. If fibropapilloma-associated turtle herpesvirus behaves similarly, environmental persistence could be important in natural disease transmission, especially in areas of high turtle density. Other factors that could contribute to viral persistence and spread include mechanical vectors, such as leeches, which have been shown to carry sufficient viral loads (up to 10 million copies) to be a potential vector ${ }^{70}$.

Virus-associated papillomas and carcinomas are also described in several marine cetacean and sirenian species in freeranging and managed populations (TABLE 1). In wildlife, tumours of the genital tract are important if they interfere with successful breeding, pregnancy or parturition. In one study, benign genital papillomas were present in $66.7 \%$ of dusky dolphins and $48.5 \%$ of Burmeister's porpoises ${ }^{71}$, and were considered important enough to interfere with copulation in $10 \%$ of Burmeister's porpoises $^{71,72}$.

Genital tract carcinoma is an emerging disease in California sea lions. Before the early 1980s, malignant tumours of any type were only rarely reported in pinnipeds ${ }^{41,73,74}$. However, from 1979 to $1994,18 \%$ of sexually mature sea lions that were found stranded along the Californian coast and died during rehabilitation had histologically aggressive, widely metastatic genital transitional cell carcinomas $^{75}$. In a subsequent report, 6.3\% of California sea lions that died during a series of unusual mortality events caused by harmful algal blooms from May to October, 1998, had benign or malignant genital tumours ${ }^{53}$.

Otarine herpesvirus- 1 is the putative cause of genital carcinoma in California sea lions $\mathrm{s}^{76,77}$. This virus is consistently found in tumours examined by electron microscopy or immunohistochemical staining and by PCR of the viral DNA polymerase and terminase genes $^{76-78}$. Otarine herpesvirus-1 is a gammaherpesvirus in the genus Rhadinovirus and is closely related to human herpesvirus- 8 (REF. 76), the causative agent of Kaposi's sarcoma $^{79,80}$. Interestingly, papillomaviruses cause cervical cancer in women, and human papillomaviruses 16 and 18 are considered to be high risk for the development of malignant cancer $^{81,82}$. Surprisingly, no papillomaviruses have been detected in sea lion or other marine mammal genital tract carcinomas ${ }^{78,77}$.

The high prevalence of genital tract carcinomas in California sea lions is unprecedented in any pinniped species. Despite apparently increasing cancer prevalence, tumours have not been associated with 
Table 1 | Examples of oncogenic viruses in humans and wildlife

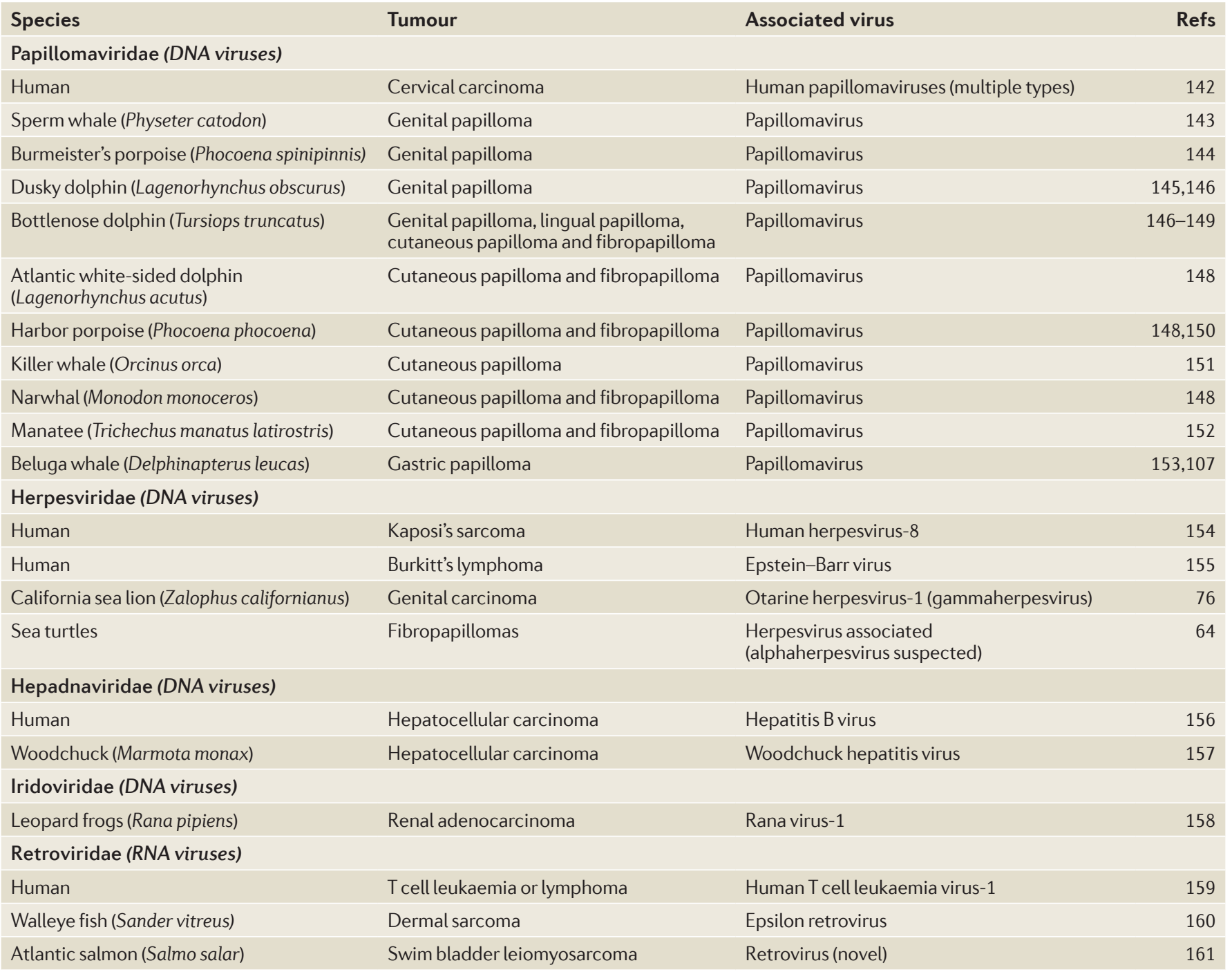

changes in population growth, which from 1975 to 2005 has been increasing at an annual rate of approximately $5.6 \%$ per year ${ }^{83}$. Continued monitoring will be essential to determine long-term population effects, identify causes for high prevalence and establish potential environmental cofactors that initiate or promote tumour development.

Cancer is a multifactorial disease. In the domestic cow infection with bovine papillomavirus 4 (the cause of oesophageal and rumenal papillomas) and exposure to ptaquiloside (a natural carcinogen in bracken fern) results in the malignant transformation of papillomas to squamous cell carcinoma ${ }^{84}$. A similar interplay may occur between viruses and chemical cofactors in sea turtle fibropapillomatosis (that is, increased incidence of fibropapillomatosis in sea turtles in polluted bodies of water $)^{59,85}$ or sea lion genital cancer: an $85 \%$ higher level of polychlorinated biphenyls is found in the blubber of sea lions with genital carcinoma relative to those without genital carcinoma ${ }^{86}$. Systematic studies assessing the potential direct or indirect roles of these contaminants in tumour development have not been performed. However, the above examples suggest that in some wild populations, carcinogenesis reflects the combined effects of multiple factors, potentially including those from the local environment.

\section{Environmental effects}

High cancer incidence is reported in wildlife populations in environments that are heavily contaminated with anthropogenic chemicals. Fish living in industrialized waterways suffer epizootics of liver and skin cancer ${ }^{87-90}$. In the population of beluga whales living in the SLE, an environment that receives effluent from aluminium smelting facilities ${ }^{91}$, cancer is the second leading cause of death'. Although several industrial and agricultural pollutants have been recovered from the estuary, polycyclic aromatic hydrocarbons (PAHs) are a major concern, as they are recognized occupational hazards and human carcinogens ${ }^{92-95}$. Causal relationships between wildlife cancers and contaminant exposure are receiving increased attention owing to risks for both wildlife and humans.

Cancer epizootics have been recognized in many species of fresh water, marine and estuarine fish. The most intensively studied epizootics have occurred in industrialized areas of the United States and Canada, such as the Great Lakes tributaries, including locations considered to be areas of concern (BOX 2), Puget Sound harbours and bays of 
the East coast of the United States. These environments are all contaminated by PAHs released from steel mills, creosote production plants and petroleum facilities ${ }^{87,88,96,97}$. Epizootic tumours reported in these areas include hepatocellular adenomas, hepatocellular carcinomas, cholangiomas and cholangiocellular carcinomas in brown bullhead catfish (Ictalurus nebulosus) ${ }^{98}$ and English sole (Parophrys vetulus) ${ }^{87,88}$, epidermal and oral papillomas in brown bullheads and white sucker fish (Catostomus commersoni) ${ }^{89}$, and (rarely) squamous cell carcinomas and melanomas in brown bullhead catfish ${ }^{90,99}$. Most affected species are bottom feeders, which suggests that a benthic lifestyle contributes to high cancer incidence through chronic exposure to contaminated sediment and consumption of contaminated invertebrates. PAH profiles from species experiencing epizootic cancer support this theory, as they reflect the PAH compounds found in the food items and compound profiles of the sediment in their habitats ${ }^{87,88,100}$.

Support for causal relationships between environmental pollutant exposure and cancer in fish has been experimental and observational. Fish laboratory models have demonstrated that dietary and intraperitoneal exposure to the PAH benzo $[a]$ pyrene $(\mathrm{BaP})$ produces hepatocellular or biliary tumours ${ }^{101}$. Additionally, skin and liver tumours have been induced by exposure to extracts prepared from PAH-contaminated sediment.
In one experiment, extracts from environmental sediment samples were painted onto the skin of brown bullhead catfish and this resulted in a $38 \%$ increased incidence of skin tumours over 2 years ${ }^{102}$. In a similar study with the same extract, dietary exposure resulted in both biliary and hepatocellular tumours ${ }^{102}$. Striking causal associations have also been made when environmental contamination decreased following closure of industrial facilities along affected waterways. For example, the prevalence of hepatocellular carcinoma in adult brown bullhead catfish living in the Black River, Ohio, United States, ranged from $22 \%$ to $39 \%$ in the early $1980 \mathrm{~s}^{103}$. At that time, age-selective mortality owing to the high cancer prevalence nearly eliminated

\section{Box 2 | Great Lakes areas of concern}

In 1972 Canada and the United States signed the Great Lakes Water Quality Agreement to address environmental issues in the Great Lakes region. In 1987, the two countries designated 43 areas of concern (AOC), locations selected owing to their proximity to urban and industrial centres, contaminated river sediment, potential sewer outflows and runoff from paved surfaces (see figure). At each location, federal, state and provincial governments developed a Remedial Action Plan (RAP), a set of guidelines to abate anthropogenic environmental influences. Success and eventual delisting are based on improvements in the chemical, physical or biological integrity of the site. Many of the Great Lakes fish populations affected by high rates of cancer occur in areas of concern. There are many methods of measuring success, but decreases in fish deformity and tumour occurrence are one milestone included in most plans, a recognition that fish serve as sentinels of the health in these habitats. So far, 3 of the 43 areas have been delisted. Two additional locations have been designated as areas of recovery.

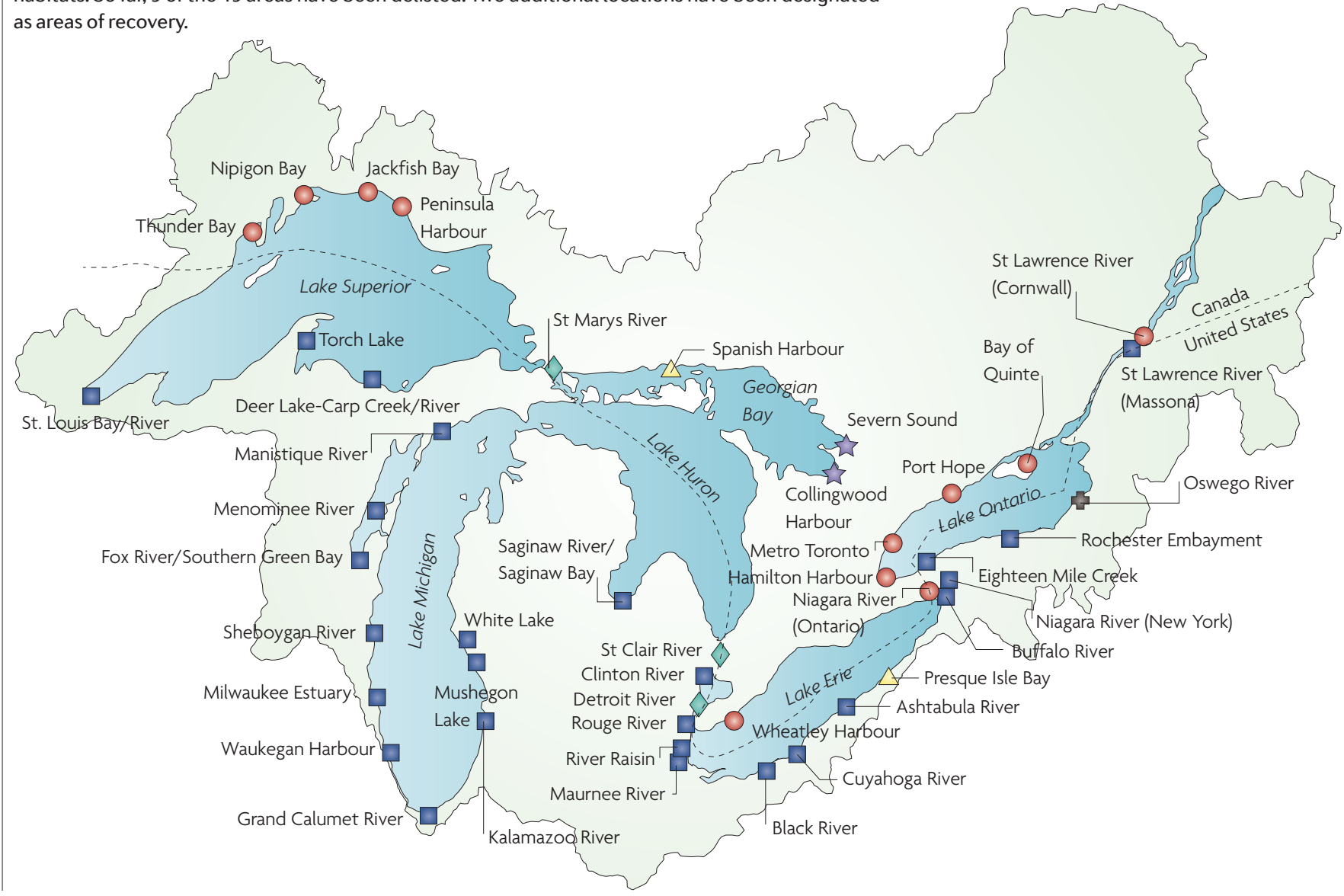


fish older than 5 years from the population ${ }^{104}$. Following a downturn in the steel industry, the coking facility located along the river closed in 1983. PAH levels in the sediment declined from $1,000 \mu \mathrm{g}$ per $\mathrm{g}$ in 1980 to $4 \mu \mathrm{g}$ per $g$ in 1987. During that time, the incidence of liver cancer in brown bullhead catfish decreased by $75 \%$ and the percentage of 5 -year-old fish in the population tripled ${ }^{103}$.

Cancer is rarely reported in wild or captive cetaceans, and the literature consists predominantly of single cases of lymphoma, leukaemias and a wide range of other neoplasms (for example, granulosa cell tumours, seminomas, and cholangio, renal, squamous and anaplastic carcinomas) $)^{9,105,106}$. However, beluga whales in the SLE exhibit a high rate of cancer. Small intestinal adenocarcinoma is the most frequent malignancy seen in SLE belugas, in contrast to that observed in other cetaceans $s^{9,107,108}$. Additionally, among marine mammals, mammary carcinoma has been reported only in SLE beluga whales ${ }^{9,109}$. Industrial and agricultural environmental contaminants have been identified in the SLE ${ }^{110-114}$. High concentrations of BaP have also been documented in SLE tissue samples, and the concentrations of polychlorinated biphenyls, dichlorodiphenyl trichloroethane, mirex, mercury and lead are much higher in beluga whales from the SLE than those living in the Arctic ${ }^{107,111,112}$. After a decline in the population owing to hunting pressures, the SLE beluga whales received endangered species status from the Canadian government in 1980, but since that time there has been no evidence of population recovery ${ }^{9,115}$. Comparative mortality data from the isolated SLE beluga whales and a population of beluga whales in a less contaminated environment in northwest Alaska indicate that beluga whales from the SLE die at an earlier age, in part owing to the high rate of cancer ${ }^{9,116}$.

High environmental levels of $\mathrm{BaP}$ are proposed as an important factor in tumorigenesis in SLE beluga whales; however, this idea is contentious and the role of these agents is under active investigation. $\mathrm{BaP}$ is a potent procarcinogen, and the site of metabolism and carcinogenesis depends on the route of exposure ${ }^{117-119}$. Mice chronically exposed to oral $\mathrm{BaP}$ develop small intestinal adenocarcinomas, gastric carcinoma and papillomas of the squamous portion of the stomach $^{120,121}$. High environmental levels of $\mathrm{BaP}$ in the SLE, known human carcinogenicity and evidence from animal models has led to the theory that oral BaP exposure in beluga whales has a role in their high incidence of intestinal cancer.
The proposed source of exposure to $\mathrm{BaP}$ in SLE beluga whales is ingestion. Beluga whales dredge the sediment, feeding on large numbers of invertebrates, animals known to bioaccumulate $\mathrm{BaP}^{122,123}$. Blue mussels in the Saguenay River portion of the SLE beluga whale habitat contain $\mathrm{BaP}$ levels that are 200 times higher than in blue mussels in adjacent habitats ${ }^{124}$. PAH exposure induces cytochrome P450 1A1 (CYP1A1) expression in hepatic and extrahepatic tissues and CYP1A1 can serve as a biomarker for PAH exposure. SLE beluga whales show increased CYP1A1 expression in multiple organs (including the liver, lung, urinary bladder and testis), which is consistent with systemic PAH exposure and metabolism ${ }^{117,125}$. CYP1A1 activates PAHs into carcinogenic metabolites, and in animal models the proximal small intestine contains the highest concentrations of CYP1A1 (REF. 126). Therefore, in SLE beluga whales it has been suggested that ingested $\mathrm{BaP}$ induces small intestinal enzyme activity, resulting in the high incidence of intestinal neoplasia observed ${ }^{9}$ (FIG. 1).

Relationships between tumour development and environmental contamination are strongly suggested by scientific data and circumstantial evidence from wildlife studies. Tumour epizootics in fish and the high cancer rate in the SLE beluga whale population are important indicators of ecosystem health. Care and caution must be applied to the selection of tumours used as environmental indicators. Some epizootic cancers are solely viral (TABLE 1) or genetic in origin and therefore would not serve as appropriate indicators of environmental contamination. For example, spontaneous nephroblastomas of Japanese eels (Anguilla japonica) contain a mutant gene with a high level of homology to the human Wilm's tumour suppressor (WT1) gene ${ }^{127}$. Therefore, only certain tumours can be indicators of environmental contamination and ecosystem health. Similarities of high cancer incidence and tumour type between species support the conclusion of common risk factors in shared environments and show the value of wildlife populations as important indicators of environmental discord.

\section{Conclusion and future directions}

Wildlife cancer reveals itself as a series of challenges and opportunities for conservation. The above examples include cases in which cancer has limited population growth or has caused population declines through the novel mechanism of allograft transmission, viral oncogenesis and the effects of carcinogenic environmental contaminants.
However, the list of examples is short and a more complete understanding of the role of tumours in wildlife population dynamics and the individual and interactive factors that drive tumorigenesis across a wide range of wildlife species is lacking but necessary.

Health monitoring, disease surveillance and scientific inquiry focused on understanding basic biology and interactive factors in wildlife cancer are crucial to our understanding of wildlife health, the role of cancer in wildlife populations and our ability to identify, assess and mitigate the risks for disease development in wildlife populations. Key elements for improving

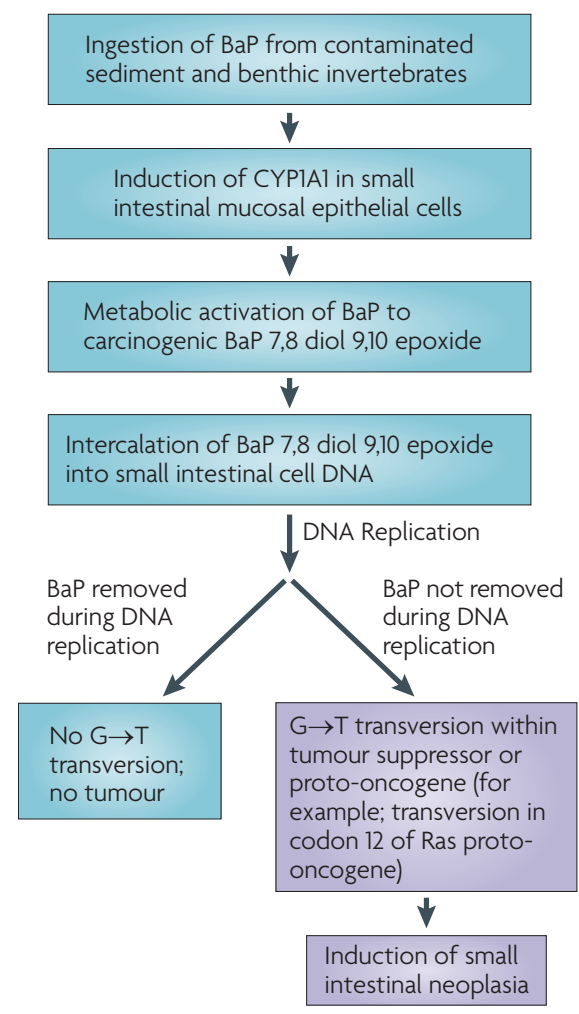

Figure 1 | Proposed mechanism of BaP small intestinal carcinogenesis in beluga whales. Environmental exposure to the procarcinogen benzo[a]pyrene $(\mathrm{BaP})$ is thought to have a role in the high incidence of small intestinal neoplasia in beluga whales in the St Lawrence River Estuary. The proposed mechanism involves intestinal exposure through ingestion of contaminated prey items and sediment followed by induction of cytochrome P450 1A1 (CYP1A1) in small intestinal epithelial cells. CYP1A1 is responsible for oxidation and metabolism of $\mathrm{BaP}$ to the carcinogen ( $\mathrm{BaP} 7,8$ diol 9,10 epoxide). The activated carcinogen preferentially binds DNA at the exocyclic nitrogen of the guanine residue, which is required for base pairing, resulting in the potential for $\mathrm{G} \rightarrow$ T transversion during DNA replication and disruption of tumour suppressors or proto-oncogenes. 
current limitations that exist in each of these key activities include identifying, coordinating and expanding existing surveillance networks; increasing and developing capacity for disease diagnostics and epidemiology; securing increased funding for multi-disciplinary scientific research and training aimed at identifying the complex mechanisms involved in wildlife tumorigenesis; integrating human and animal health surveillance systems; creating a unified animal and environmental health database; and improving current relationships, as well as establishing new collaborative relationships with stakeholders and policy makers. Expanding the range and scope of each of these activities will have broad and direct benefits for wildlife and also potentially for the environment and humans. Early recognition of cancer epizootics in wildlife has the potential to drive timely environmental mitigation and influence environmental policy. Building capacity and leveraging expertise across disciplines will result in expanded opportunities for advancing our understanding of normal cellular processes and mechanisms of carcinogenesis as has occurred historically in investigations of wildlife cancer. As we look to the future, there is tremendous opportunity for achieving imagined advances in our understanding of wildlife health, contributing to the protection and conservation of wildlife and creating a healthier planet.

Denise McAloose and Alisa L. Newton are at Pathology and Disease Investigation, Global Health Program, Wildlife Conservation Society, 2300 Southern Boulevard, Bronx, New York, New York 10460, USA. Correspondence to D.M. e-mail: dmcaloose@wcs.org doi: 10.1038/nrc2665 Corrected online 26 July 2009

1. Rous, P. A sarcoma of the fowl transmissible by an agent separable from the tumor cells. J. Exp. Med. 13, 397-411 (1911).

2. Malumbres, M. $\&$ Barbacid, M. RAS oncogenes: the first 30 years. Nature Rev. Cancer 3, 459-465 (2003).

3. Klaus, A. $\&$ Birchmeier, W. Wnt signalling and its impact on development and cancer. Nature Rev. Cancer 8, 387-398 (2008).

4. Karesh, W. \& Cook, R. One world - one health Clin. Med. 9, 5-7 (2009).

5. Centers for Disease Control and Prevention. The burden of chronic diseases and their risk factors: national and state perspectives 2004. US Department of Health and Human Services [online], http://www.cdc.gov/nccdphp/burdenbook2004 (2004).

6. Aguirre, A. A. et al. Pathology of fibropapillomatosis in olive ridley turtles Lepidochelys olivacea nesting in Costa Rica. J. Aquat. Anim. Health 11, 283-289 (1999).

7. Stroud, R. K. \& Roffe, T. J. Causes of death in marine mammals stranded along the Oregon coast. J. Wildl. Dis. 15, 91-97 (1979)

8. Crooks, K. R., Scott, C. A. \& Van Vuren, D. H. Exotic disease and an insular endemic carnivore, the island fox. Biol. Conserv. 98, 55-60 (2001).
9. Martineau, D. et al. Cancer in wildlife, a case study: beluga from the St. Lawrence estuary, Québec Canada. Environ. Health Perspect. 110, 285-292 (2002).

10. Hamede, R. K., McCallum, H. \& Jones, M. Seasonal, demographic and density-related patterns of contact between Tasmanian devils (Sarcophilus harrisii): implications for transmission of devil facial tumour disease. Austral. Ecol. 33, 614-622 (2008).

11. McCallum, H. et al. Distribution and impacts of Tasmanian devil facial tumor disease. EcoHealth 4 318-325 (2007).

12. Hawkins, C. et al. Emerging disease and population decline of an island endemic, the Tasmanian devil Sarcophilus harrisii. Biol. Cons. 131, 307-324 (2006).

13. Pyecroft, S. et al. Towards a case definition for devil facial tumour disease: what is it? EcoHealth 4, 346-351 (2007).

14. Loh, R. et al. The pathology of devil facial tumor disease (DFTD) in Tasmanian devils (Sarcophilus harrisii). Vet. Pathol. 43, 890-895 (2006).

15. Loh, R. et al. The immunohistochemical characterization of devil facial tumor disease (DFTD) in the Tasmanian devil (Sarcophilus harrisii). Vet. Pathol. 43, 896-903 (2006).

16. McCallum, H., Barlow, N. \& Hone, J. How should pathogen transmission be modelled? Trends Ecol. Evol. 16, 295-300 (2001).

17. Lachish, S., Jones, M. \& McCallum, H. The impact of disease on the survival and population growth rate of the Tasmanian devil. J. Anim. Ecol. 76, 926-936 (2007)

18. Pyecroft, S. Transmission trials: devil facial tumor disease. Devil Facial Tumour Diseases: Senior Scientist's Scientific Forum 18 [online], http://tassiedevil.com.au/ docs/DFTD\%20forum\%20abstracts.pdf (2007).

19. Pearse, A. \& Swift, K. Allograft theory: transmission of devil facial-tumour disease. Nature 439, 549 (2006)

20. Siddle, H. V. et al. Transmission of a fatal clonal tumor by biting occurs due to depleted MHC diversity in a threatened carnivorous marsupial. Proc. Natl Acad. Sci. USA 104, 16221-16226 (2007).

21. Kreiss, A. et al. Assessment of cellular immune responses of healthy and diseased Tasmanian devils (Sarcophilus harrisii). Dev. Comp. Immunol. 32 544-553 (2008)

22. Kreiss, A., Wells, B. \& Woods, G. M. The humoral immune response of the Tasmanian devil (Sarcophilus harrisii) against horse red blood cells. Vet. Immunol. Immunopathol. (in the press).

23. Woods, G. et al. The immune response of the Tasmanian devil (Sarcophilus harrisii) and devil facial tumour disease. EcoHealth 4, 338-345 (2007)

24. Murgia, C et al. Clonal origin and evolution of a transmissible cancer. Cell 126, 477-487 (2006).

25. Gandhi, M. J. \& Strong, D. M. Donor derived malignancy following transplantation: a review. Cell Tissue Bank 8, 267-286 (2007).

26. Aguirre-Ghiso, J. A. Models, mechanisms and clinical evidence for cancer dormancy. Nature Rev. Cancer 7 834-846 (2007)

27. Ajithkumar, T. V. et al. Management of solid tumours in organ-transplant recipients. Lancet Oncol. 8, 921-932 (2007).

28. Mozos, E. et al. Immunohistochemical characterization of canine transmissible venereal tumor. Vet. Pathol. 33, 257-263 (1996).

29. Das, U. \& Das, A. K. Review of canine transmissible venereal sarcoma. Vet. Res. Commun. 24, 545-556 (2000).

30. Mukaratirwa, S. \& Gruys, E. Canine transmissible venereal tumour: cytogenetic origin, immunophenotype, and immunobiology. A review. Vet. Q. 25, 101-111 (2003).

31. VonHoldt, B. M. \& Ostrander, E. A. The singular history of a canine transmissible tumor. Cell 126 , 445-447 (2006)

32. Cohen, D. The canine transmissible venereal tumor: a unique result of tumor progression. Adv. Cancer Res. 43, 75-112 (1985)

33. Epstein, R. B. \& Bennett, B. T. Histocompatibility typing and course of canine venereal tumors transplanted into unmodified random dogs. Cancer Res. 34, 788-793 (1974).

34. Liu, C. et al. Transient downregulation of monocytederived dendritic-cell differentiation, function, and survival during tumoral progression and regression in an in vivo canine model of transmissible venereal tumor. Cancer Immunol. Immunother. 57, 479-491 (2008)
35. Hsiao, Y. et al. Interactions of host IL-6 and IFN- $\gamma$ and cancer-derived TGF- $\beta 1$ on MHC molecule expression during tumor spontaneous regression. Cancer Immunol. Immunother. 57, 1091-1104 (2008).

36. Evermann, J. F. et al. Comparative features of a coronavirus isolated from a cheetah with feline infectious peritonitis. Virus Res. 13, 15-27 (1989).

37. O'Brien, S. J. et al. Genetic basis for species vulnerability in the cheetah. Science 227, 1428-1434 (1985).

38. Lachish, S., Jones, M. \& McCallum, H. The impact of disease on the survival and population growth rate of the Tasmanian devil. J. Anim. Ecol. 76, 926-936 (2007).

39. McCallum, H. Tasmanian devil facial tumour disease: lessons for conservation biology. Trends Ecol. Evol. 23 631-637 (2008)

40. Lloyd-Smith, J. O., Getz, W. M. \& Westerhoff, H. V. Frequency-dependent incidence in models of sexually transmitted diseases: portrayal of pair-based transmission and effects of illness on contact behaviour. Proc. Biol. Sci. 271, 625-634 (2004)

41. Gulland, F. M., Lowenstine, L. J. \& Spraker, T. R. in Marine Mammal Medicine 2nd edn (eds Dierauf, L. A. \& Gulland, F. M.) 521-550 (CRC, Boca Raton, 2001).

42. Hilker, F. M., Langlais, M. \& Malchow, H. The Allee effect and infectious diseases: extinction, multistability, and the (dis-)appearance of oscillations. Am. Nat. 173, 72-88 (2009).

43. Angulo, E. et al. Double Allee effects and extinction in the island fox. Conserv. Biol. 21, 1082-1091 (2007).

44. Jones, M. et al. Conservation management of Tasmanian devils in the context of an emerging, extinction-threatening disease: devil facial tumor disease. EcoHealth 4, 326-337 (2007).

45. Peterson, M. J. \& Silvy, N. J. Reproductive stages limiting productivity of the endangered Attwater's prairie chicken. Conserv. Biol. 10, 1264-1276 (1996)

46. Bennett, M. D. Western barred bandicoots in health and disease. Thesis, Murdoch Univ. (2008).

47. Drew, M. L. et al. Reticuloendotheliosis in captive greater and Attwater's prairie chickens. J. WildI. Dis. 34, 783-791 (1998)

48. Bennett, M. D. et al. Hematologic characteristics of captive western barred bandicoots (Perameles bougainville) from Western Australia. Vet. Clin. Pathol. 36, 348-353 (2007)

49. Barbosa, T. et al. Pathogenicity and transmission of reticuloendotheliosis virus isolated from endangered prairie chickens. Avian Dis. 51, 33-39 (2007).

50. Drechsler, Y. et al. An avian, oncogenic retrovirus replicates in vivo in more than $50 \%$ of $\mathrm{CD}^{+}$and CD8+ $\mathrm{T}$ lymphocytes from an endangered grouse. Virology 386, 380-386 (2009).

51. Bennett, M. D. et al. In situ hybridization to detect bandicoot papillomatosis carcinomatosis virus type 1 in biopsies from endangered western barred bandicoots (Perameles bougainville). J. Gen. Virol. 89, 419-423 (2008).

52. Woolford, L. et al. Cutaneous papillomatosis and carcinomatosis in the Western barred bandicoot (Perameles bougainville). Vet. Pathol. 45, 95-103 (2008).

53. Gulland, F. Domoic acid toxicity in California sea lions (Zalophus californianus) stranded along the central California coast, May-October 1998. National Oceanic and Atmospheric Administration [online] http://www.nmfs.noaa.gov/pr/pdfs/health/domoic acid california.pdf (2000).

54. Adnyana, W., Ladds, P. W. \& Blair, D. Observations of fibropapillomatosis in green turtles (Chelonia mydas) in Indonesia. Aust. Vet. J. 75, 736-742 (1997).

55. Herbst, L. H. Fibropapillomatosis of marine turtles. Annu. Rev. Fish. Dis. 4, 389-425 (1994).

56. Balazs, G. H. Research plan for marine turtle fibropapilloma. NOAA Technical Memorandum NMFS [online], http://swfsc.noaa.gov/publications/TM/ SWFSC/NOAA-TM-NMFS-SWFSC-156.PDF (1991).

57. Work, T. M. et al. Retrospective pathology survey of green turtles Chelonia mydas with fibropapillomatosis in the Hawaiian Islands, 1993-2003. Dis. Aquat. Organ. 62, 163-176 (2004).

58. Williams, E. et al. An epizootic of cutaneous fibropapillomas in green turtles Chelonia mydas of the Caribbean: part of a panzootic? J. Aquat. Anim. Health 6, 70-78 (1994).

59. Herbst, L. H. \& Klein, P. A. Green turtle fibropapillomatosis: challenges to assessing the role of environmental cofactors. Environ. Health Perspect. 103 Suppl. 4, 27-30 (1995). 
60. Huerta, P. et al. First confirmed case of fibropapilloma in a leatherback turtle (Dermochelys coriacea). Proceedings of the Twentieth Annual Symposium on Sea Turtle Biology and Conservation [online], http://www.nmfs.noaa.gov/pr/pdfs/species/ turtlesymposium 2000.pdf (2000).

61. Guillen, L. \& Villalobos, J. P. Papillomas in Kemp's ridley turtles. Proceedings of the Nineteenth Annual Symposium on Sea Turtle Conservation and Biology [online], http://www.seaturtle.org/ists/docs/19turtle. pdf (1999).

62. D’Amato, A. F. \& Moraes-Neto, M. First documentation of fibropapillomas verified by histology in Eretmochelys imbricata. Marine Turtle Newsletter [online], http://www.seaturtle.org/mtn/archives/ mtn89/mtn89p12 shtml (2000).

63. Herbst, L. H. et al. Comparative pathology and pathogenesis of spontaneous and experimentally induced fibropapillomas of green turtles (Chelonia mydas). Vet. Pathol. 36, 551-564 (1999).

64. Lu, Y. et al. Detection of herpesviral sequences in tissues of green turtles with fibropapilloma by polymerase chain reaction. Arch. Virol. 145, 1885-1893 (2000).

65. Greenblatt, R J et al Genomic variation of the fibropapilloma-associated marine turtle herpesvirus across seven geographic areas and three host species. J. Virol. 79, 1125-1132 (2005).

66. Herbst, L. H. Experimental transmission of green turtle fibropapillomatosis using cell-free tumor extracts. Dis. Aquat. Org. 22, 1-12 (1995).

67. Yu, Q. et al. Amplification and analysis of DNA flanking known sequences of a novel herpesvirus from green turtles with fibropapilloma. Arch. Virol. 145, 2669-2676 (2000).

68. Herbst, L. H. et al. Differential gene expression associated with tumorigenicity of cultured green turtle fibropapilloma-derived fibroblasts. Cancer Genet. Cytogenet. 129, 35-39 (2001).

69. Curry, S. S. et al. Persistent infectivity of a diseaseassociated herpesvirus in green turtles after exposure to seawater. J. Wildl. Dis. 36, 792-797 (2000).

70. Greenblatt, R. J. et al. The Ozobranchus leech is a candidate mechanical vector for the fibropapillomaassociated turtle herpesvirus found latently infecting skin tumors on Hawaiian green turtles (Chelonia mydas). Virology 321, 101-110 (2004)

71. Van Bressem, M. F. et al. Genital and lingual warts in small cetaceans from coastal Peru. Dis. Aquat. Org. 26, 1-10 (1996)

72. Van Bressem, M. F., Van Waerebeek, K. \& Raga, J. A. A review of virus infections of cetaceans and the potential impact of morbilliviruses, poxviruses and papillomaviruses on host population dynamics. Dis. Aquat. Org. 38, 53-65 (1999)

73. Sweeney, J. C. \& Gilmartin, W. G. Survey of diseases in free-living California sea lions. J. Wildl. Dis. 10 370-376 (1974)

74 Newman S J \& Smith S. A Marine mammal neoplasia: a review. Vet. Pathol. 43, 865-880 (2006).

75. Gulland, F. M. et al. Metastatic carcinoma of probable transitional cell origin in 66 free-living California sea lions (Zalophus californianus), 1979 to 1994 . J. Wildl. Dis. 32, 250-258 (1996).

76. King, D. P. et al. Otarine herpesvirus-1: a nove gammaherpesvirus associated with urogenital carcinoma in California sea lions (Zalophus californianus). Vet. Microbiol. 86, 131-137 (2002).

77. Buckles, E. L. et al. Otarine herpesvirus-1, not papillomavirus, is associated with endemic tumours in California sea lions (Zalophus californianus). J. Comp. Pathol. 135, 183-189 (2006)

78. Lipscomb, T. P. et al. Common metastatic carcinoma of California sea lions (Zalophus californianus) evidence of genital origin and association with nove gammaherpesvirus. Vet. Pathol. 37, 609-617 (2000)

79. Chang, Y. et al. Identification of herpesvirus-like DNA sequences in AIDS-associated Kaposi's sarcoma. Science 266, 1865-1869 (1994).

80. Ambroziak, J. A. et al. Herpes-like sequences in HIV-infected and uninfected Kaposi's sarcoma patients. Science 268, 582-583 (1995).

81. Nelson, J. H., Averette, H. E. \& Richart, R. M. Cervical intraepithelial neoplasia (dysplasia and carcinoma in situ) and early invasive cervical carcinoma. CA Cancer J. Clin. 39, 157-178 (1989).

82. Smith, J. S. et al. Age-specific prevalence of infection with human papillomavirus in females: a global review. J. Adolesc. Health 43 (Suppl. 1), S5.e1-S5.eb2 (2008).
83. NOAA Fisheries Service, California sea lion (Zalophus californianus californianus): US stock. National Marine Fisheries Service [online], http://www.nmfs noaa.gov/pr/pdfs/sars/po2007slca.pdf (2007).

84. Jarrett, W. F. H. et al. High incidence area of cattle cancer with a possible interaction between an environmental carcinogen and a papilloma virus. Nature 274, 215-217 (1978).

85. Foley, A. M. et al. Fibropapillomatosis in stranded green turtles (Chelonia mydas) from the eastern United States (1980-1998): trends and associations with environmental factors. J. Wildl. Dis. 41, 29-41 (2005)

86. Ylitalo, G. M. et al. The role of organochlorines in cancer-associated mortality in California sea lions (Zalophus californianus). Mar. Pollut. Bull. 50, 30-39 (2005)

87. Malins, D. C. et al. Toxic chemicals in marine sediment and biota from Mukilteo, Washington: relationships with hepatic neoplasms and other hepatic lesions in English sole (Parophrys vetulus). J. Natl Cancer Inst. 74, 487-494 (1985).

88. Malins, D. C. et al. Toxic chemicals in sediments and biota from a creosote-polluted harbor: relationships with hepatic neoplasms and other hepatic lesions in English sole (Parophrys vetulus). Carcinogenesis 6 1463-1469 (1985).

89. Smith, I., Ferguson, H. \& Hayes, M. Histopathology and prevalence of epidermal papillomas epidemic in brown bullhead, Ictalurus nebulosus (Lesueur) and white sucker, Catostomus commersoni (Laceped) populations from Ontario, Canada. J. Fish. Dis. 12, 373-388 (1989)

90. Baumann, P. C., Smith, I. R. \& Metcalfe, C. D. Linkages between chemical contaminants and tumors in benthic Great lakes fish. J. Great Lakes Res. 22, 131-152 (1996).

91. Martel, L. et al. Polycyclic aromatic hydrocarbons in sediments from the Saguenay Fjord, Canada. Bull. Environ. Contam. Toxicol. 37, 133-140 (1986).

92. World Health Organization International Agency for Research on Cancer. IARC Monographs on the Evaluation of Carcinogenic Risks to Humans. Overall Evaluations of Carcinogenicity: An Updating of IARC Monographs Volumes 1 to 42. Suppl. 7. [online] http://monographs.iarc.fr/ENG/Monographs/suppl7/ suppl7.pdf (1998)

93. International Agency for Research on Cancer. IARC Monographs on the Evaluation of Carcinogenic Risks to Humans. IARC Monographs Vol. 32 (World Health Organization, 1983)

94 Bosetti, C., Boffetta, P. \& La Vecchia, C. Occupational exposures to polycyclic aromatic hydrocarbons, and respiratory and urinary tract cancers: a quantitative review to 2005. Ann. Oncol. 18, 431-446 (2007)

95. Boffetta, P., Jourenkova, N. \& Gustavsson, P. Cancer risk from occupational and environmental exposure to polycyclic aromatic hydrocarbons. Cancer Causes Control 8, 444-472 (1997).

96. Malins, D. C et al. Field and laboratory studies of the etiology of liver neoplasms in marine fish from Puget Sound. Environ. Health Perspect. 71, 5-16 (1987)

97. Black, J. J. \& Baumann, P. C. Carcinogens and cancers in freshwater fishes. Environ. Health Perspect. 90 27-33 (1991).

98. Blazer, V. S. et al. Diagnostic criteria for proliferative hepatic lesions in brown bullhead Ameiurus nebulosus. Dis. Aquat. Org. 72, 19-30 (2006).

99. Sakamoto, K. \& White, M. Dermal melanoma with schwannoma-like differentiation in a brown bullhead catfish (Ictalurus nebulosus). J. Vet. Diagn. Invest. 14, 247-250 (2002)

100. Maccubbin, A. E. et al. Evidence for polynuclear aromatic hydrocarbons in the diet of bottom-feeding fish. Bull. Environ. Contam. Toxicol. 34, 876-882 (1985).

101. Hendricks, J. D. et al. Hepatocarcinogenicity of benzo[a]pyrene to rainbow trout by dietary exposure and intraperitoneal injection. J. Natl Cancer Inst. 74 839-851 (1985).

102. Black, J. J. et al. in Water Chlorination Chemistry, Environmental Impact and Health Effects (eds Jolley, R. L et al.) 415-427 (Plenum, New York, 1984).

103. Baumann, P. C. \& Harshbarger, J. C. Decline in liver neoplasms in wild brown bullhead catfish after coking plant closes and environmental PAHs plummet. Environ. Health Perspect. 103, 168-170 (1995).

104. Baumann, P. C., Harshbarger, J. C. \& Hartman, K. J. Relationship between liver tumors and age in brown bullhead populations from two Lake Erie tributaries. Sci. Total Environ. 94, 71-87 (1990).
105. Landy, R. B. in The Comparative Pathology of Zoo Animals (eds Montali, R. G. \& Migaki, G.) 579-584 (Smithsonian Institution Press, Washington DC 1980).

106. Newman, S. J. \& Smith, S. A. Marine mammal neoplasia: a review Vet Pathol 43, 865-880 (2006)

107. De Guise, S., Lagacé, A. \& Béland, P. Tumors in St. Lawrence beluga whales (Delphinapterus leucas). Vet. Pathol. 31, 444-449 (1994).

108. Martineau, D. et al. Intestinal adenocarcinomas in two beluga whales (Delphinapterus leucas) from the estuary of the St. Lawrence River. Can. Vet. J. 36 563-565 (1995).

109. Mikaelian, I. et al. Metastatic mammary adenocarcinomas in two beluga whales (Delphinapterus leucas) from the St. Lawrence Estuary, Canada. Vet. Rec. 145, 738-739 (1999).

110. Martineau, D. et al. Pathology of stranded beluga whales (Delphinapterus leucas) from the St. Lawrence Estuary, Québec, Canada. J. Comp. Pathol. 98, 287-311 (1988)

111. Muir, D. C. G. et al. Persistent organochlorines in beluga whales (Delphinapterus leucas) from the St. Lawrence River estuary-I. Concentrations and patterns of specific PCBs, chlorinated pesticides and polychlorinated dibenzo- $p$-dioxins and dibenzofurans. Environ. Pollut. 93, 219-234 (1996).

112. Muir, D. C. G. et al. Persistent organochlorines in beluga whales (Delphinapterus leucas) from the St. Lawrence River estuary-II. Temporal trends, 1982-1994. Environ. Pollut. 93, 235-245 (1996).

113. Hobbs, K. E. et al. PCBs and organochlorine pesticides in blubber biopsies from free-ranging St. Lawrence River Estuary beluga whales (Delphinapterus leucas), 1994-1998. Environ. Pollut. 122, 291-302 (2003)

114. Martineau, D. et al. Pathology and toxicology of beluga whales from the St. Lawrence Estuary, Quebec Canada. Past, present and future. Sci. Total Environ. 154, 201-215 (1994).

115. De Guise, S. et al. Possible mechanisms of action of environmental contaminants on St. Lawrence beluga whales (Delphinapterus leucas). Environ. Health Perspect. 103 (Suppl. 4), 73-77 (1995).

116. Martineau, D. et al. St. Lawrence beluga whales, the river sweepers? Environ. Health Perspect. 110, A562-A564 (2002).

117. Klaunig, J. E. \& Kamendulis, L. M. in Casarett \& Doull's Toxicology: The Basic Science of Poisons 329-379 (McGraw-Hill Medical, New York, 2008).

118. Kane, A. B. \& Kumar, V. in Robbins and Cotran Pathologic Basis of Disease 270 (Elsevier Saunders, Philadelphia, 2005)

119. Timbrell, J. A. in Principles of Biochemical Toxicology 295-297 (CRC, London, 2008).

120. Culp, S. J. et al. A comparison of the tumors induced by coal tar and benzo[a]pyrene in a 2-year bioassay. Carcinogenesis 19, 117-124 (1998).

121 Culp, S. J. et al. DNA adduct measurements, cell proliferation and tumor mutation induction in relation to tumor formation in B6C3F1 mice fed coal tar or benzo[a]pyrene. Carcinogenesis 21, 1433-1440 (2000).

122. Rust, A. J. et al. Relationship between metabolism and bioaccumulation of benzo[a]pyrene in benthic invertebrates. Environ. Toxicol. Chem. 23, 2587-2593 (2004).

123. Rocher, B. et al. Genotoxicant accumulation and cellular defence activation in bivalves chronically exposed to waterborne contaminants from the Seine River. Aquat. Toxicol. 79, 65-77 (2006)

124. Cossa, D., Picard-Bérubé, M. \& Gouygou, J. P. Polynuclear aromatic hydrocarbons in mussels from the Estuary and Northwestern Gulf of St. Lawrence, Canada. Bull. Environ. Contam. Toxicol. 31, 41-47 (1983).

125. Wilson, J. Y. et al. Systemic effects of arctic pollutants in beluga whales indicated by CYP1A1 expression. Environ. Health Perspect. 113 1594-1599 (2005).

126. Zhang, Q. Y. et al. Characterization of rat smal intestinal cytochrome P450 composition and inducibility. Drug Metab. Dispos. 24, 322-328 (1996)

127. Harshbarger, J. C. \& Slatick, M. S. Lesser known aquarium fish tumor models. Mar. Biotechnol. 3 , S115-S129 (2001)

128. Lombard, L. S. \& Witte, E. J. Frequency and types of tumors in mammals and birds of the Philadelphia Zoological Garden. Cancer Res. 19, 127-141 (1959). 
129. Effron, M. Griner, L \& Benirschke, K. Nature and rate of neoplasia found in captive wild mammals, birds, and reptiles at necropsy. J. Natl Cancer Inst. 59, 185-198 (1977).

130. Ryan, M. J., Hill, D. L. \& Whitney, G. D. Malignant chromatophoroma in a gopher snake. Vet. Pathol. 18 , 827-829 (1981)

131. Suedmeyer, W. K. et al. Diagnosis and clinical management of multiple chromatophoromas in an eastern yellowbelly racer (Coluber constrictor flaviventris). J. Zoo WildI. Med. 38, 127-130 (2007).

132. Montali, R. J., Hoopes, P. J. \& Bush, M. Extrahepatic biliary carcinomas in Asiatic bears. J. Natl Cancer Inst. 66, 603-608 (1981).

133. Miller, R. E. et al. Hepatic neoplasia in two polar bears. J. Am. Vet. Med. Assoc. 187, 1256-1258 (1985).

134. Lair, S. et al. Epidemiology of neoplasia in captive black-footed ferrets (Mustela nigripes), 1986-1996. J. Zoo Wildl. Med. 33, 204-213 (2002).

135. Le Calvez, S., Perron-Lepage, M. \& Burnett, R. Subcutaneous microchip-associated tumours in B6C3F1 mice: a retrospective study to attempt to determine their histogenesis. Exp. Toxicol. Pathol. 57, 255-265 (2006)

136. Tillmann, T. et al. Subcutaneous soft tissue tumours at the site of implanted microchips in mice. Exp. Toxicol. Pathol. 49, 197-200 (1997).

137. Elcock, L. E. et al. Tumors in long-term rat studies associated with microchip animal identification devices. Exp. Toxicol. Pathol. 52, 483-491 (2001).

138. Pessier, A. et al. Soft tissue sarcomas associated with identification of microchip implants in two small zoo mammals. Proc. Am. Assoc. Zoo Vet. 139 (1999).

139. Siegal-Willott, J. et al. Microchip-associated leiomyosarcoma in an Egyptian fruit bat (Rousettus aegyptiacus). J. Zoo Wildl. Med. 38, 352-356 (2007).

140. McAloose, D., Munson, L. \& Naydan, D. K. Histologic features of mammary carcinomas in zoo felids treated with melengestrol acetate (MGA) contraceptives. Vet. Pathol. 44, 320-326 (2007).

141. Harrenstien, L. A., Munson, L. \& Seal, U. S. Mammary cancer in captive wild felids and risk factors for its development: a retrospective study of the clinical behavior of 31 cases. J. Zoo Wildl. Med. 27, 468-476 (1996).
142. Pilotti, S. et al. Histologic evidence for an association of cervical intraepithelial neoplasia with human papilloma virus infection. Diagn. Gynecol. Obstet. 4, 357-362 (1982).

143. Lambertsen, R. et al. Genital papillomatosis in sperm whale bulls. J. Wildl. Dis. 23, 361-367 (1987).

144. Van Bressem, M. et al. Genital warts in Burmeister's porpoises: characterization of Phocoena spinipinnis papillomavirus type 1 (PsPV-1) and evidence for a second, distantly related PsPV. J. Gen. Virol. 88 1928-1933 (2007).

145. Van Bressem, M. F. et al. Genital diseases in the Peruvian dusky dolphin (Lagenorhynchus obscurus) J. Comp. Pathol. 122, 266-277 (2000).

146. Cassonnet, P. et al. in The World Marine Mammal Science Conference, Monaco 25 (1998).

147. Bossart, G. D. et al. Orogenital neoplasia in Atlantic bottlenose dolphins (Tursiops truncatus). Aquatic Mammals 31, 473-480 (2005).

148. Geraci, J., Palmer, N. \& St Aubin, D. Tumors in cetaceans: analysis and new findings. Can. J. Fish. Aquat. Sci. 44, 1289-1300 (1987).

149. Rehtanz, M. et al. Isolation and characterization of the first American bottlenose dolphin papillomavirus: Tursiops truncatus papillomavirus type 2. J. Gen. Virol. 87, 3559-3565 (2006).

150. Van Bressem, M. F. et al. Cutaneous papillomavirus infection in a harbour porpoise (Phocoena phocoena) from the North Sea. Vet. Rec. 144, 592-593 (1999).

151. Bossart, G. D. et al. Cutaneous papillomaviral-like papillomatosis in a killer whale. Mar. Mam. Sci. 12, 274-281 (1996)

152. Bossart, G. D. et al. Viral papillomatosis in Florida manatees (Trichechus manatus latirostris). Exp. Mol. Pathol. 72, 37-48 (2002).

153. De Guise, S., Lagacé, A. \& Bêland, P. Gastric papillomas in eight St. Lawrence beluga whales (Delphinapterus leucas). J. Vet. Diagn. Invest. 6 385-388 (1994).

154. Memar, O. M., Rady, P. L. \& Tyring, S. K. Human herpesvirus-8: detection of novel herpesvirus-like DNA sequences in Kaposi's sarcoma and other lesions. J. Mol. Med. 73, 603-609 (1995).

155. Gunvên, P. et al. Epstein-Barr virus in Burkitt's lymphoma and nasopharyngeal carcinoma. Antibodies to EBV associated membrane and viral capsid antigens in Burkitt lymphoma patients. Nature 228 , 1053-1056 (1970)

156. Blumberg, B. S. et al. The relation of infection with the hepatitis B agent to primary hepatic carcinoma. Am. J. Pathol. 81, 669-682 (1975).

157. Summers, J., Smolec, J. M. \& Snyder, R. A virus similar to human hepatitis B virus associated with hepatitis and hepatoma in woodchucks. Proc. Natl Acad. Sci. USA 75, 4533-4537 (1978)

158. Granoff, A. Herpesvirus and the Lucké tumor. Cancer Res. 33, 1431-1433 (1973).

159. Poiesz, B. J. et al. Isolation of a new type $C$ retrovirus (HTLV) in primary uncultured cells of a patient with Sézary T-cell leukaemia. Nature 294, 268-271 (1981).

160. Martineau, D. et al. Molecular characterization of a unique retrovirus associated with a fish tumor. J. Virol. 66, 596-599 (1992).

161. Paul, T. A. et al. Identification and characterization of an exogenous retrovirus from Atlantic salmon swim bladder sarcomas. J. Virol. 80, 2941-2948 (2006).

\section{Acknowledgements}

The authors thank D. Lyden, W. Karesh and T. Chang, whose thoughtful suggestions, especially early on, helped shape the content of the manuscript. They also acknowledge $D$. Joly and the anonymous reviewers, whose critical reviews and comments markedly improved the final version.

DATABASES

Entrez Gene: http://www.ncbi.n/m.nih.gov/entrez/query.

fcgi?db=gene

MYC ISRC IWT1

UniProtKB: http://www.uniprot.org

CYP1A1 | interferon- $\alpha$ | interleukin- 6 | 553 | TGF- $\beta$ |

FURTHER INFORMATION

NOAA Fisheries Service: http://www.nmfs.noaa.gov/

U.S. Environmental Protection Agency web site - Great

Lakes Areas of Concern: http://www.epa.gov/glnpo/aoc/

Wildlife Conservation Society: http://www.wcs.org/

ALL LINKS ARE ACTIVE IN THE ONLINE PDF 